\title{
Historical lessons to watch your assumptions about aging: relevance to the role of International Psychogeriatrics
}

\author{
"The greatest obstacle to discovery is not ignorance - it \\ is the illusion of knowledge."
}

Daniel J. Boorstin

For too long, too many in science and society alike viewed aging as offering little that was of value. There was a collective illusion of knowledge that aging was characterized by inevitable, unalterable decrements in functioning that led to a dismal destiny in later life. This was a widespread perspective on aging, especially in the scientific community. To the extent that scientists considered aging as a wasteland of scientific opportunity, they had little interest in studying it. By not studying aging, little new was discovered about it, thereby preserving negative assumptions about what later life held for all of us. Both Freud and Piaget, for example, viewed development of the mind as essentially a first quarter of the life-cycle phenomenon psychologically for Freud, intellectually for Piaget (Freud, 1978; Piaget, 1972).

But by the mid-1970s the first of two fundamental sea changes in how aging was perceived began to emerge. New hypotheses were generated that attempted to explain negative changes accompanying aging, not as representing normal aging but instead reflecting age-associated problems modifiable disorders.

For the scientist, the idea that a negative change is caused by a problem, and not normal aging, creates a new sense of opportunity to modify the problem. For the policy-maker, this recognition results in a new sense of responsibility to do something about the problem. This sea change in thinking about modifiable age-associated problems launched serious attention to growth of the field of geriatrics in the last quarter of the 20th century.

The transition from seeing progressive, unalterable negative changes with aging as being one's destiny to a new view of modifiable age-associated problems was an enormous leap in itself. While this was happening it was too big a leap to go the next step - to see that aging could be accompanied by potential beyond problems. But by the end of

First published online 26 February 2009. the 20th century, the view that aging could be accompanied by potential beyond problems was emerging. The "potential" focus of aging reflected the emergence of the second major conceptual sea change about aging and is reflected in my book The Creative Age (Cohen, 2000), the first book to focus totally on creativity and aging, published at the start of the 21 st century. The ultimate manifestation of potential with aging is creativity.

I had written my first major piece on creativity and aging in 1988 in my book The Brain in Human Aging (Cohen, 1988). It was here that my new sense of the history of the field was germinating, and, along with it, a sense that the time was right internationally to bring the dissemination of the latest knowledge about aging to a new level especially in relation to psychogeriatrics. Hence, I was honored and thrilled to be invited to be the first Editor-in-Chief of the new journal International Psychogeriatrics, launched in the spring of 1989. Here, I felt, was an opportunity on an international scale to confront the illusions of knowledge about aging through a new worldwide sharing of the latest findings and developments in psychogeriatrics for addressing both disorders and health-promotion with aging. This goal is reflected in the opening editorial to Volume 1, Number 1, that I wrote with my colleagues - Associate Editors Manfred Bergener, M.D. and Kazuo Hasegawa, M.D., and Managing Editor Sanford I. Finkel, M.D. The first paragraph says it well:

Welcome to International Psychogeriatrics. It is with pride, excitement, and a sense of challenge that we launch this first issue of our new journal. Why this new Journal? The impetus and the credit go to the field-specifically to the growing community of researchers, teachers, and clinicians around the globe who are interested in and contribute to psychogeriatric knowledge. This truly is the historic moment in the fields of gerontology and geriatrics, a period marked by the coming together of societal concern and scientific curiosity about issues of aging and the problems of the elderly. It is a moment not confined to any one nation, nor to any one continent; that is what makes it all the more important and exciting. It is in this context that this new journal, international in scope, is being launched. (Cohen et al., 1989) 


\section{Watch your assumptions about the brain, mind and behavior with aging}

A long series of false assumptions and conclusions lacking evidence-based research to support them have interfered with research, practice and policies relevant to psychogeriatrics. A number of the best and brightest in the history of science have contributed to these flawed perspectives.

\section{Sigmund Freud}

In 1905 Sigmund Freud (1856-1939) asserted that "About the age of 50, the elasticity of the mental processes on which treatment depends, is, as a rule, lacking. Old people are no longer educable." Freud expressed this view despite the fact that after 50 he produced some of his most intellectually elastic and outstanding works: his Introductory Lectures on Psychoanalysis in 1917 (age 61); The Ego and the Id in 1923 (age 67); Civilization and Its Discontents in 1930 (age 74). This perspective certainly did not encourage work with older persons. Fortunately, in 1919, Karl Abraham offered a much more positive view, but it was not until the fourth quarter of the 20th century that evidence-based research on psychotherapy with older patients more substantially corrected the picture as to what was possible in psychogeriatric work with older adults (Abraham, 1979; Gallagher and Thompson, 1983).

\section{Jean Piaget}

Jean Piaget (1896-1980) was the father of the field of intellectual development. He described four developmental stages, with the fourth and final reflecting the highest level of intellectual growth at the end of adolescence and early adulthood. $\mathrm{He}$ referred to this highest stage of intellectual development as being characterized by "Formal Thought." To the extent that further intellectual development was not described with aging, interest in lifelong learning was impeded along with limited program development in this area.

Fortunately, Piaget's students continued his work, and they discovered that intellectual development continues with the emergence of a fifth stage as we enter middle age and the second half of life-that of "Postformal Thought" (Sinnott, 1999). Whereas formal thought was characterized by strong analytic reasoning and a focus on finding the right answer, postformal thought added strength in synthetic reasoning and the recognition that in many situations there are competing and contradictory solutions, as opposed to a single correct answer.

\section{Ramón y Cajal}

In his 1913 masterpiece Degeneration and Regeneration, Nobel Laureate Santiago Ramón y Cajal (1852-1934) wrote that in the adult brain "the nerve paths are something fixed, ended, immutable. Everything may die, nothing may be regenerated" (Doidge, 2007). Influenced until the end of the 20th century by the work of this giant in the field of neuroscience and other leading neuroscientists, the view among the top brain researchers was that neurogenesis was impossible. Their gold standard in this reasoning was that neurons are not like skin cells or liver cells: neurons cannot regenerate. Hence, neurogenesis is impossible.

But at the end of 1998, a nest of stem cells was discovered in the hippocampus that led to the genesis of new neurons (Kempermann et al., 2004). The best and the brightest had been unable to step outside the box with their assumptions that linked neurogenesis to regeneration. They failed to hypothesize that through another process, de novo brain cells could be produced (Cohen, 2006). New findings on brain plasticity have catalyzed the exploding attention to brain fitness, which is as important now to most older persons as physical fitness.

\section{New concepts and findings about potential with aging, apart from problems}

While remarkable progress was being made in treating problems and minimizing loss with aging, little attention was being paid to the reality of potential with aging and how tapping this potential could promote health. It was a huge step to establish that decline could be minimized as reflected in the view of successful aging. It was still too big a step to look beyond problems to actual potential with aging. In their important paper, Rowe and Kahn (1987) effectively brought the field to the pinnacle of the "problem focus" through their concept of successful aging, defined as "people who demonstrate little or no loss in a constellation of physiologic functions", regarding these individuals as "more broadly successful in physiologic terms" (Rowe and Kahn, 1987). What their elegant concept lacks, though, is attention to where actual growth and development can occur with aging - views and findings emerging from the new focus on potential with aging that are challenging previous limited or negative assumptions about the capacity for positive change with age. This occurred with the second major sea change in thinking about aging and is reflected in the "Creativity and Aging Study" discussed below. 


\section{Pragmatic creativity with aging}

With the new focus on potential, many researchers have, for example, described the concept of "pragmatic creativity" or "practical intelligence," finding that it actually increases with aging (Willis and Schaie, 1986). In my own work on psychological growth and development in the second half of life, I have described four psychological growth phases that continue through to the end of the life cycle (Cohen, 2006). The second of the four - the liberation phase - helps us understand the reporting of increased pragmatic creativity with aging. The liberation phase in effect begins to phase in during our 50s, as we are approaching our mid-50s. It then matures further as we enter and move through our $60 \mathrm{~s}$, and what is experienced stays with us. The liberation phase is characterized by metaphorical friendly inner voices that say to us, "Why not?"; "If not now, when?"; and very powerfully, "What can they do to me?" This latter feeling instills us with a new sense of confidence, comfort, and courage to try something new - even something bold. It is illustrated in the following example from my own family:

My in-laws, Howard and Gisele Miller, were stuck. They had just emerged from the Washington, DC subway system into a driving snowstorm. Both in their early 70 s, they were coming to our house for dinner and needed a cab, since it was too far to walk. But it was rush hour and no cabs stopped. Howard tried calling us to get a lift, but both my wife Wendy and I were stuck in traffic and weren't home yet, and it was before we all had cell phones.

As his fingers began to turn numb from the cold, Howard noticed the steamy windows of a pizza shop across the street, and a smile came on his face. He and Giselle walked through the slush to the shop, stepped up to the counter, and ordered a large pizza for home delivery. When the cashier asked where to deliver it, Howard gave him our address, and added, "Oh, there's one more thing."

"What's that?" the cashier asked.

"We want you to deliver us with it," Howard said.

And that's how they arrived - pizza in hand - for dinner that night.

\section{Old age that adds as it takes away}

In later life more than any other part of the life cycle, if an older person experiences a loss, it is too often seen as the beginning of irreversible decline. But research on creativity and aging reveals that loss in later life can be a powerful motivator for positive change. There is nothing romantic about loss, but it is part of the human condition that when we experience a decline in a capacity that we cannot restore, we often attempt to transcend this loss by tapping into or developing new strategies. This is well illustrated by Henri Matisse who, in his early 80 s, suffered heart disease, lung disorder and gastrointestinal problems that sapped his energy, making it impossible to paint the way he used to. But it was not good enough for him to be able to paint the old way - less well. He responded by advancing a new art form - his Cut Outs - where in creating them his experience was that of cutting pure color.

William Carlos Williams was a pediatrician better known for his poetry. In his 60 s he suffered a stroke that left him with paralysis, preventing him from continuing his practice of medicine. He became very depressed and was hospitalized for nearly a year in his late 60s. But he emerged from this seemingly overwhelming challenge by turning full time to poetry, and 10 years later, in his late 70 s, published Pictures from Bruegel, which was awarded a Pulitzer Prize. In his second half of life poetry, Carlos Williams wrote about old age that adds as it takes away (Cohen, 2001).

\section{The creativity and aging study}

My own contribution to research on potential and creativity with aging in relation to health promotion began in 2001 with a grant from the National Endowment for the Arts, in coordination with the National Institutes of Health and four other sponsors, to conduct a rigorous national study examining the effects of community-based art programs on the health and functioning of older adults. The study compared the physical and mental health and social functioning of 150 older persons involved in arts programs to a comparable group (controls) of 150 adults not in such programs. All the participants were aged 65 or older and most were living independently when the study started; both groups were comparable in their health and functioning at the start of the study. The adults who were not in the arts group were free to socialize, attend classes, or do any of their normal activities, including art (though none in the control group became involved in rigorous and sustained participatory art programs). We wanted to see if it was the creative process involved in the arts programs that made a difference, rather than the mere fact that these participants were engaged in a regular, structured social situation.

This study was theory driven, being based on two prior bodies of research on aging showing positive health outcomes from two dynamics - a sense of control and social support (Rodin, 1986; Avlund et al., 1998). The sense of control research shows that older adults who experience a growing sense of 
mastery have positive health outcomes; those in the art programs on a weekly basis vividly experienced their growing sense of mastery. The cardiovascular literature demonstrates the value of social supports in improving outcomes from heart attacks and coronary bypass surgery. Each art program offered a participatory and very supportive group experience. In these studies, the two dynamics - sense of control and social support - were combined, creating a synergy for improved health outcomes. Both factors had previously been shown to influence positive immune system changes, and contributed to the growth of the field of psychoneuroimmunology and the mind/body movement (Pert et al., 1998; KiecoltGlaser et al., 2002).

The arts groups met for 35 weekly meetings analogous to a college course. There were also between-session assignments as well as exhibitions and concerts. For example, a chorale at one site gave some 10 concerts a year in addition to their regular weekly practice sessions.

We assessed each person's health and social functioning with comprehensive questionnaires at the beginning of the programs, at the half-way mark, and again at the end, two years after starting. Our hypothesis was that the people participating in the arts programs (the intervention group) would show less decline than the control group who did not participate in those programs. We were pleasantly surprised, therefore, when the initial results exceeded these expectations. Many people in the arts groups stabilized their health, i.e. they didn't decline at all. And, as a whole, those in the art programs actually improved their overall health. This occurred in a group of people with an average age of 80 , which is greater than the current life expectancy!

Here are the major findings from the first phase of the study, which was conducted in the Washington, DC area. (Similar paired study groups were researched in Brooklyn at "Elders Share the Arts," under the direction of Susan Perlstein, and in San Francisco at the "Center for Elders and Youth in the Arts," under the direction of Jeff Chapline; data are still being analyzed but point to improved overall health in these two sites as well.) All the results were statistically significant, reflecting real differences between the two study groups.

Compared to the control group, those who participated in the community arts program:

- had better health after two years (those in the control group reported that their health was not as good after the same elapsed time; see Figure 1);

- had fewer doctor visits (though both groups had more visits compared to two years earlier);

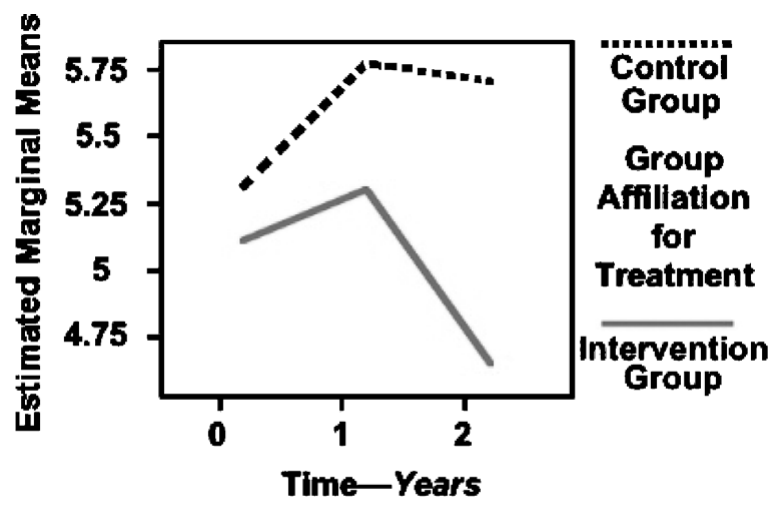

Mean Number of Health Problems for Intervention $(\mathrm{N}=61$ ) and Comparison $(\mathrm{N} .=57)$ Groups Across. Time

Figure 1. The problems in the intervention group fall over time but rise in the control group. Source: Cohen et al., 2007.

- used fewer medications (note: in the U.S.A., where more than 36 million Medicare eligible older adults now receive coverage for medication, 8 cents per day reduction in medication usage extrapolated for the year would result in a saving of $\$ 1$ billion dollars; a saving of $\$ 1$ a day would extrapolate to $\$ 13$ billion a year saved);

- felt less depressed;

- were less lonely;

- had higher morale; and

- were more socially active.

Clearly the community-based art programs, tapping into potential, were having a real effect on health promotion and disease prevention. These effects, in turn, support the independence of the individuals and their ability to live in their communities, reflecting a reduction in risk factors driving the need for long-term care (Cohen et al., 2006; 2007).

The bottom line is that "It's never too late for positive change with aging."

Dickens' subliminal psychogeriatric message in the case history of Ebenezer Scrooge - a.k.a. $A$ Christmas Carol - is to watch your assumptions about aging and that it's never too late to get out of a rut regardless of age. This reality is conveyed in the ahead-of-its-time 1843 outreach intervention by a multidisciplinary team of three, employing psychodynamic dream work -50 years before Freud's classic work on "the Interpretation of Dreams" - to treat a chronic undiagnosed depression (Cohen, 2002).

For the past 20 years, International Psychogeriatrics has done a similarly outstanding job of disseminating knowledge and dispelling false assumptions about aging, to enhance the positive impact of psychogeriatric know-how. 


\section{Gene D. COHEN}

Director of the Center on Aging, Health and Humanities, Professor of Health Care Sciences and Professor of Psychiatry and Behavioral Sciences, George Washington University, Kensington, MD, U.S.A.

Email: GENCOwdc@aol.com

website: www.gwumc.edu/cahh

\section{References}

Abraham, K. (1979). Applicability of psycho-analytic treatment to patients at an advanced age. In: H. C. Abraham (ed.), Selected Papers on Psychoanalysis. New York: Brunner/Mazel.

Avlund, K., Damsgaard, M. T. and Holstein, E. E. (1998). Social relations and mortality: an eleven year follow-up study of 70-year-old men and women in Denmark. Social Science and Medicine, 47, 635-643.

Cohen, G. D. (1988). The Brain in Human Aging. New York: Springer Publishing Company.

Cohen, G. D. (2000). The Creative Age. New York: Avon Books.

Cohen, G. D. (2001). The Creative Age: Awakening Human Potential in the Second Half of Life. New York: Harper Collins.

Cohen, G. D. (2002). Depression in later life: an historic account demonstrates the importance of making the diagnosis. Geriatrics, 57, 38-39.

Cohen, G. D. (2006). The Mature Mind: The Positive Power of the Aging Brain. New York: Basic Books.

Cohen, G. D., Bergener, M., Hasegawa, K. and Finkel, S. I. (1989). Editorial. International Psychogeriatrics, 1, 3-4.

Cohen, G. D., Perlstein, S., Chapline, J., Kelly, J., Firth, K. and Simmens, S. (2006). The impact of professionally conducted cultural programs on the physical health, mental health, and social functioning of older adults. The Gerontologist, 46, 726-734.
Cohen, G. D., Perlstein, S., Chapline, J., Kelly, J., Firth, K. and Simmens, S. (2007). The impact of professionally conducted cultural programs on the physical health, mental health, and social functioning of older adults - 2-year results. Fournal of Aging, Humanities and the Arts, 1, 5-22.

Doidge, N. (2007). The Brain that Changes Itself. New York: Viking.

Freud, S. (1978). On psychotherapy (1905). In J. Strachey (ed. and trans.), Complete Psychological Works (Volume 7). London: Hogarth Press.

Gallagher, D. and Thompson, L. (1983). Effectiveness of psychotherapy for both endogenous and nonendogenous depression in older adult outpatients. Fournal of Gerontology, 38, 707-712.

Kempermann, G., Wiskott, L. and Gage, F. H. (2004). Functional significance of adult neurogenesis. Current Opinion in Neurobiology, 14, 186-191.

Kiecolt-Glaser, J. K., McGuire, L., Robles, T. F. and Glaser, R. (2002). Emotions, morbidity, and mortality: new perspectives from psychoneuroimmunology. Annual Review of Psychology, 53, 83-107.

Pert, C., Dreher, H. E. and Ruff, R. (1998). The psychosomatic network: foundations of mind-body medicine. Alternative Therapies, 4, 30-41.

Piaget, J. (1972). Intellectual evolution from adolescence to adulthood. Human Development, 15, 1-12.

Rodin, J. (1986). Aging and health: effects of the sense of control. Science, 233, 1271-1276.

Rowe, J. W. and Kahn, R. L. (1987). Human aging: usual and successful. Science, 237, 143-149.

Sinnott, J. D. (1999). Creativity and postformal thought: why the last stage is the creative stage. In: C. E. Adams-Price (ed.), Creativity And Successful Aging. New York: Springer Publishing Company.

Willis, S. L. and Schaie, K. W. (1986). Practical intelligence in later adulthood. In: R. J. Sternberg and R. K. Wagner (eds.), Practical Intelligence: Nature and Origins of Competence in the Everyday World. Cambridge: Cambridge University Press. 